\title{
CYTOGENETIC STUDIES ON NATURAL POPULATIONS OF GRASSHOPPERS WITH SPECIAL REFERENCE TO B CHROMOSOMES
}

\author{
I. GONISTA BICOLOR* \\ M. SANNOMIYA \\ Institute of Biology, Oita University, Oita, Japan
}

Received 29.v.73

\begin{abstract}
SUMMARY
In Gonista bicolor

$\left(2 n\right.$ ? $\left.=22+\mathrm{XX}+0 \sim 2 \mathrm{~B}_{1}+0 \sim 7 \mathrm{~B}_{2}, 2 n \hat{\sigma}=22+\mathrm{XO}+0 \sim 3 \mathrm{~B}_{1}+0 \sim 16 \mathrm{~B}_{2}\right)$ frequencies of males with $B_{1}$ 's in four natural populations were 29,35, 14 and 72 per cent, respectively, and those with $\mathrm{B}_{2}{ }^{\prime}$ s were $97,95,76$ and 92 per cent, respectively.

$\mathrm{B}_{1}$ 's were mitotically highly stable in the germ line of the males as well as in the somatic lines of both sexes. The mean numbers of $B_{1}$ 's per male were $0.34,0.50,0.14$ and 1.00 , respectively, in the four populations.

$\mathrm{B}_{2}$ 's were mitotically unstable in somatic lines of both sexes. In the germ line of the males the instability of $\mathrm{B}_{2}$ 's was a characteristic confined to an early stage of development. Therefore, numbers of $\mathrm{B}_{2}$ 's in primary spermatocytes were variable from follicle to follicle within the individuals, though they were usually constant within the follicles. Mean numbers of $B_{2}$ 's per follicle were also different among the four populations, i.e. 2.96, 1.77, 1.37, and 2.97, respectively.

Different tissues showed different mean numbers of $\mathrm{B}_{\mathbf{2}}$ 's per cell; higher numbers in the ovariole walls than in the gastirc caeca (females), and higher numbers in the germ line than in the gastric caeca (males). An estimation of original zygotic numbers of the males indicated that different mean numbers of $\mathrm{B}_{2}$ 's between somatic and germ lines and between different somatic lines were accounted for on the basis of tendency to elimination of $\mathrm{B}_{2}$ 's in the somatic lines.
\end{abstract}

\section{INTRODUCTION}

B GHROMOSOMES (supernumerary or accessory chromosomes) have been reported in a large number of plant and animal species and extensive literatures have been reviewed by White (1954), Müntzing (1958, 1966), Rutishauser (1960) and Battaglia (1964). There are two kinds of B chromosomes, mitotically stable and unstable. Thus four Acrididian species have stable and five have unstable type of B's (cf. John and Lewis, 1968, p. 49). Additional instances are Acrida lata with a stable type of B (Kayano, Sannomiya and Nakamura, 1970), and Atractomorpha bedeli with an unstable type of B (Sannomiya and Kayano, 1969). In studying chromosomal variation in an Acrididian grasshopper, Gonista bicolor de Haan $(2 n$ ㅇ $=22+\mathrm{XX}$, $\left.2 n \sigma^{*}=22+\mathrm{XO}\right)$, the writer encountered both mitotically stable and unstable types of B's, which are dealt with in the present paper.

* Contribution from the Institute of Biology, Oita University, No. 85. 


\section{Materials and methods}

A total of 9 females and 109 males of Gonista bicolor were collected at four well separated locations: 35 males at $G$ (Goshi-mura, Kikuchi-gun, Kumamoto-ken, in 1959), 20 males at $K s$ (Kashii, Fukuoka-shi, Fukuokaken, in 1959), 29 males at Ot (Ozi-machi, Oita-shi, Oita-ken, in 1961), 9 females and 25 males at $K g$ (Kagamiyama, Karatsu-shi, Saga-ken, in 1970). The testes were fixed with the fluid devised by Newcomer (1953) and squashed in iron-acetocarmine, or stained in alcoholic hydrochloric acidcarmine and squashed in 45 per cent acetic acid (Snow, 1963), a single follicle being squashed in each preparation. Somatic chromosomes were studied in 9 females and 13 males from $K g$, in which the cells of the gastric caeca or the cells of the ovariole walls (female) were used. The males after removal of testis were injected with $0.02 \mathrm{c}^{3}$ of 0.03 per cent aqueous solution of demecolcine for 18-24 hours. To females $0.05 \mathrm{c}^{3}$ of the solution was applied. The gastric caeca and ovarioles were fixed with acetic alcohol $(1: 3)$ and stained with alcoholic hydrochloric acid-carmine (Snow, 1963).

\section{Observation}

\section{(i) Basic complement and B-chromosomes}

The somatic chromosome complement of $G$. bicolor basically consisted of $2 n=22+\mathrm{XX}$ in the female and $2 n=22+\mathrm{XO}$ in the male. The basic complement showed 11 bivalents plus one $\mathrm{X}(11 \mathrm{II}+\mathrm{X})$ in the primary

TABLE 1

Pairing of B's at $M I$ in primary spermatocytes

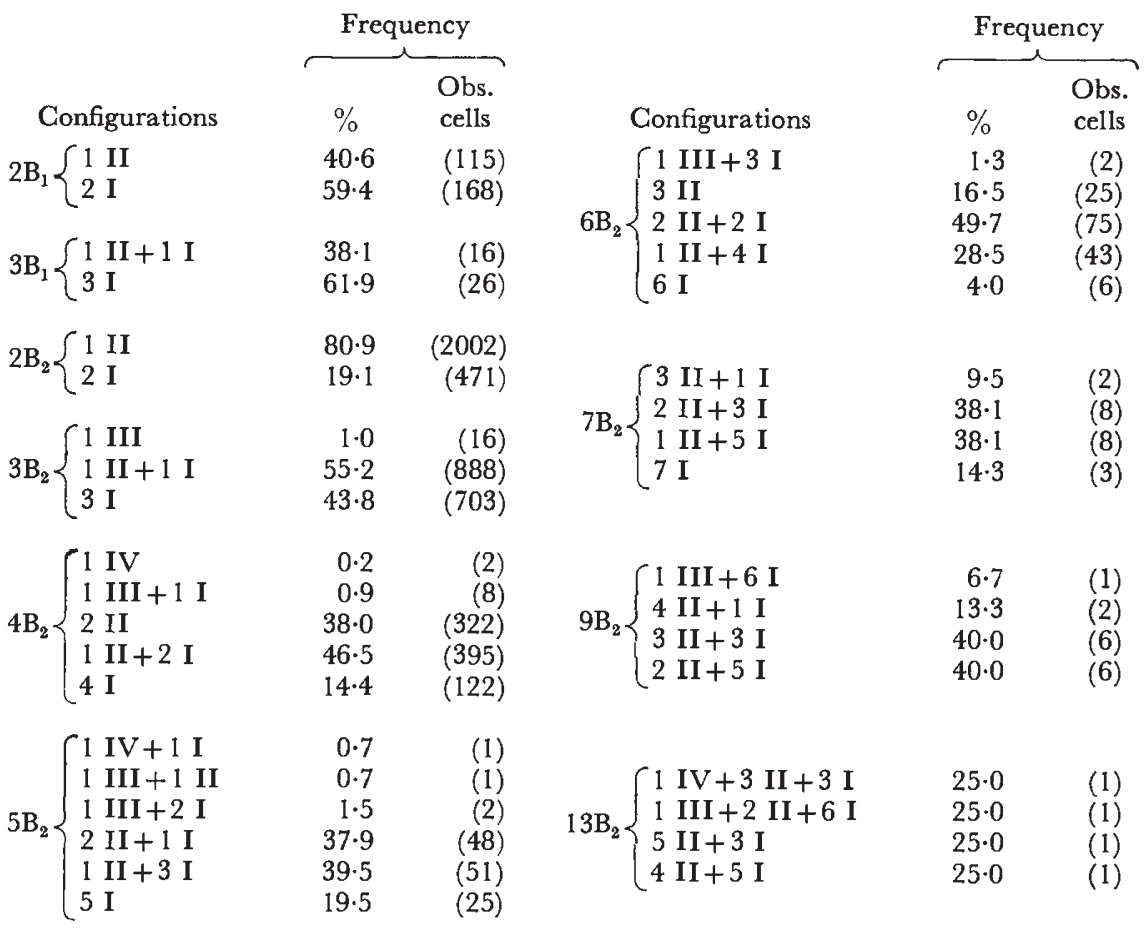


spermatocytes. Most of the individuals were found to contain $\mathrm{B}$ chromosomes $\left(0 \sim 3 \mathrm{~B}_{1}\right.$ 's and $0 \sim 16 \mathrm{~B}_{2}$ 's) in addition to the basic complement. All the $\mathrm{B}$ chromosomes were telocentric, as well as the autosomes and the $\mathrm{X}$ chromosome (plate I, figs. 1-2). $\mathrm{B}_{1}$ was medium sized (as large as the 7th or 8th autosomes) with a large heterochromatic block at the proximal region (plate I, fig. 3). Except at pachytene, diplotene, and diakinesis, $\mathrm{B}_{1}$ 's were not distinguishable from the autosomes. $B_{2}$ 's were smaller than the smallest A's and were stained like as the proximal region of the A's (plate I, figs. 3-7). In primary spermatocytes no pairing occurred between $B_{1}$ and $B_{2}$, while $B_{1}$ 's paired into bivalent and $B_{2}$ 's paired into bivalents, trivalent, etc. (table 1 ; plate I, figs. 3-7).

\section{(ii) Mitotic stability and instability of $B$ 's}

Numbers of $B_{1}$ 's were variable among individuals but they were generally constant within the individuals in the somatic cells as well as in the primary spermatocytes. There were two exceptions which showed slight variation in the number of $B_{1}$ 's in primary spermatocytes within the follicles as follows:

$\begin{array}{cccc}\text { Case } & 2 \mathrm{~B}_{1} & 3 \mathrm{~B}_{1} & \begin{array}{c}\text { Total } \\ \text { cells }\end{array} \\ 1 & 40 & 1 & 41 \\ 2 & 3 & 18 & 21\end{array}$

On the other hand, in 62 out of 98 males with $\mathrm{B}_{2}$ 's the number of $\mathrm{B}_{2}$ 's per cell varied from follicle to follicle within the individuals, while in the remaining 36 males the numbers of $\mathrm{B}_{2}$ 's were constant within the individuals (table 2; appendix tables 1-4). In spite of inter-follicular variation, no variation in the number of $\mathrm{B}_{2}$ 's was found within the follicles, other than in three exceptional cases out of 683 follicles as follows:

$\begin{array}{cccccccccc}\text { Case } & \mathrm{OB}_{2} & \mathrm{IB}_{2} & 2 \mathrm{~B}_{2} & 3 \mathrm{~B}_{2} & 4 \mathrm{~B}_{2} & 5 \mathrm{~B}_{2} & 6 \mathrm{~B}_{2} & 7 \mathrm{~B}_{2} & \begin{array}{c}\text { Total } \\ \text { cells }\end{array} \\ a & 48 & - & 14 & 3 & - & - & - & - & 65 \\ b & - & - & - & - & - & 26 & - & 8 & 34 \\ c & - & - & 34 & 20 & - & - & - & - & 54\end{array}$

In the cells of the gastric caeca numbers of $B_{2}$ 's varied from cell to cell as well as in the cells of the ovariole walls. In comparison between average number of $B_{2}$ 's per cell of the gastric caeca and that per primary spermatocyte, 10 males showed higher numbers in primary spermatocytes than in the cells of the gastric caeca, two males showed equal numbers, and one male showed a lower number in the primary spermatocytes than in the cells of the gastric caeca (table 3 ). The mean number of $\mathrm{B}_{2}$ 's per primary spermatocyte in 13 males was $2 \cdot 86$ and that per cell of the gastric caeca was 2.09 . In comparisons made between gastric caeca and ovariole walls in 9 females, the mean number of $\mathrm{B}_{2}$ 's per cell was higher in the ovariole walls (1.97) than in the gastric caeca (l.63) (table 4).

\section{(iii) Populations}

It was a surprise to find that all the males from $G s, K s$ and $K g$ and the great majority of the males from $O t$ had either $\mathrm{B}_{1}$ or $\mathrm{B}_{2}$ or both. Table 5 shows frequencies of B's in the four natural populations (cf. appendix 
tables 1-4). The frequencies of $B_{1}$ 's are significantly different between the populations $\left(\chi^{2}=29.52\right.$, d.f. $\left.=3, p<0.01\right)$. Overall means of numbers of $\mathrm{B}_{2}$ 's per follicle were different between the populations: 2.96 in $G s, 1.77$ in $K s, 1.37$ in $O t$, and 2.97 in $K g\left(\mathbf{F}_{\mathbf{1 0 5}}^{\mathbf{3}}=10.05,0.05>\mathrm{P}>0.01\right.$; table 6 ; $\mathrm{cf}$.

TABLE 2

Number of $B_{2}$ 's in males of $\mathrm{G}$. bicolor from four populations, $G s, K s, O t$, and $K g$

\begin{tabular}{|c|c|c|c|c|}
\hline \multirow{2}{*}{$\begin{array}{l}\text { Range of no. of } \\
\text { Ba's per male }^{\prime}\end{array}$} & \multicolumn{4}{|c|}{ No. of males } \\
\hline & Gs & Ks & $O t$ & $\kappa g$ \\
\hline 0 & 1 & 1 & 7 & 2 \\
\hline 1 & 2 & 6 & 5 & 2 \\
\hline 2 & 4 & 1 & 6 & 1 \\
\hline 3 & 2 & - & 1 & 1 \\
\hline 4 & 2 & - & 2 & 1 \\
\hline (Sub-total) & (11) & (8) & (21) & (7) \\
\hline $0-1$ & - & 1 & - & - \\
\hline $0-2$ & 1 & - & - & - \\
\hline $1-2$ & 1 & 5 & 7 & 1 \\
\hline $1-3$ & 2 & - & - & 1 \\
\hline $1-4$ & 1 & - & - & 2 \\
\hline $1-5$ & - & - & - & 1 \\
\hline $1-9$ & 1 & - & - & - \\
\hline $2-3$ & 3 & 1 & 1 & 1 \\
\hline $2-4$ & 3 & 2 & - & 3 \\
\hline $2-5$ & 1 & 1 & - & 1 \\
\hline $2-6$ & 2 & - & - & - \\
\hline $2-13$ & 1 & - & - & - \\
\hline $3-4$ & 3 & 1 & - & 1 \\
\hline $3-5$ & 2 & - & - & 3 \\
\hline $3-6$ & 1 & - & - & 1 \\
\hline $3-7$ & - & 1 & - & - \\
\hline $4-6$ & - & - & - & 1 \\
\hline $4-7$ & - & - & - & 1 \\
\hline $4-9$ & 1 & - & - & - \\
\hline $5-6$ & 1 & - & - & - \\
\hline $6-8$ & - & - & - & 1 \\
\hline Total males & 35 & 20 & 29 & 25 \\
\hline No. of follicles obs. & 167 & 113 & 96 & \\
\hline of cells obs & 4239 & 2911 & 3810 & $\begin{array}{c}\text { not } \\
\text { counted }\end{array}$ \\
\hline $\begin{array}{l}\text { Mean no. of } B \\
\text { per follicle }\end{array}$ & $2 \cdot 96$ & $1 \cdot 77$ & 1.37 & 2.97 \\
\hline
\end{tabular}

appendix tables 1-4). In these populations the numbers of males with variable numbers of $B_{2}$ 's are positively correlated with the overall mean of numbers of $\mathrm{B}_{2}$ 's per follicle (table 7).

\section{Estimation of original zYgotic NUMBers of B's}

In respect of the mechanism concerned with the maintenance of $B_{2}$ 's in the populations, the original zygotic numbers of $\mathrm{B}_{2}$ 's in the $K g$ population were estimated by the following procedure.

First, it was assumed that the predominant follicle type of any male (table 3) represented the original zygotic number of $B_{2}$ 's from which it was developed. Thus original zygotic numbers of $B_{2}$ 's of 13 males were inferred 
की

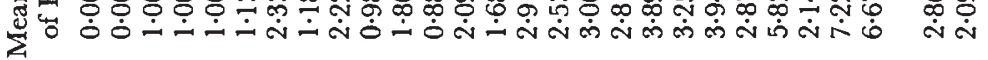

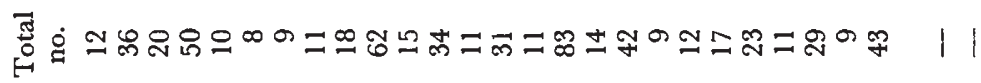
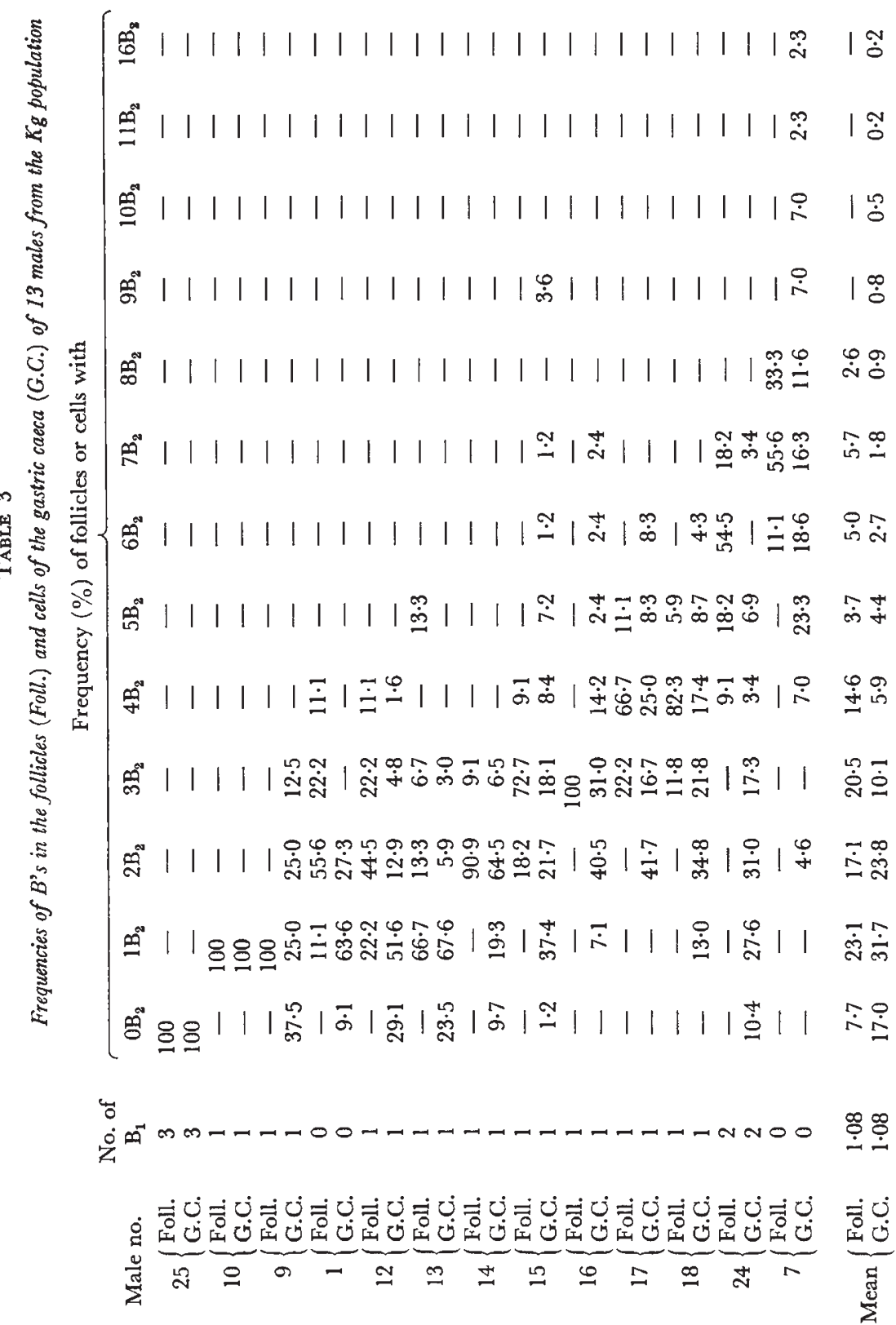
to be $0 \mathrm{~B}_{2}(1), 1 \mathrm{~B}_{2}(3), 2 \mathrm{~B}_{2}(3), 3 \mathrm{~B}_{2}(2), 4 \mathrm{~B}_{2}(2), 6 \mathrm{~B}_{2}(1)$ and $7 \mathrm{~B}_{2}(1)$, with the mean of the zygotic number 2.77 per male (number of males in parentheses, table 8). In contrast, the original zygotic numbers of $\mathrm{B}_{2}$ 's of the 13 males were inferred to be $0 B_{2}(1), 1 B_{2}(6), 2 B_{2}(5)$ and $5 B_{2}(1)$ on the basis of the frequencies of cell types in the gastric caeca (mean number of $\mathrm{B}_{2}$ 's per male $1 \cdot 62$, table 8 ).

TABLE 4

Frequencies of $B$ 's in cells of the ovariole walls (O.W.) and cells of the gastric caeca (G.C.) of 9 females from the Kg population

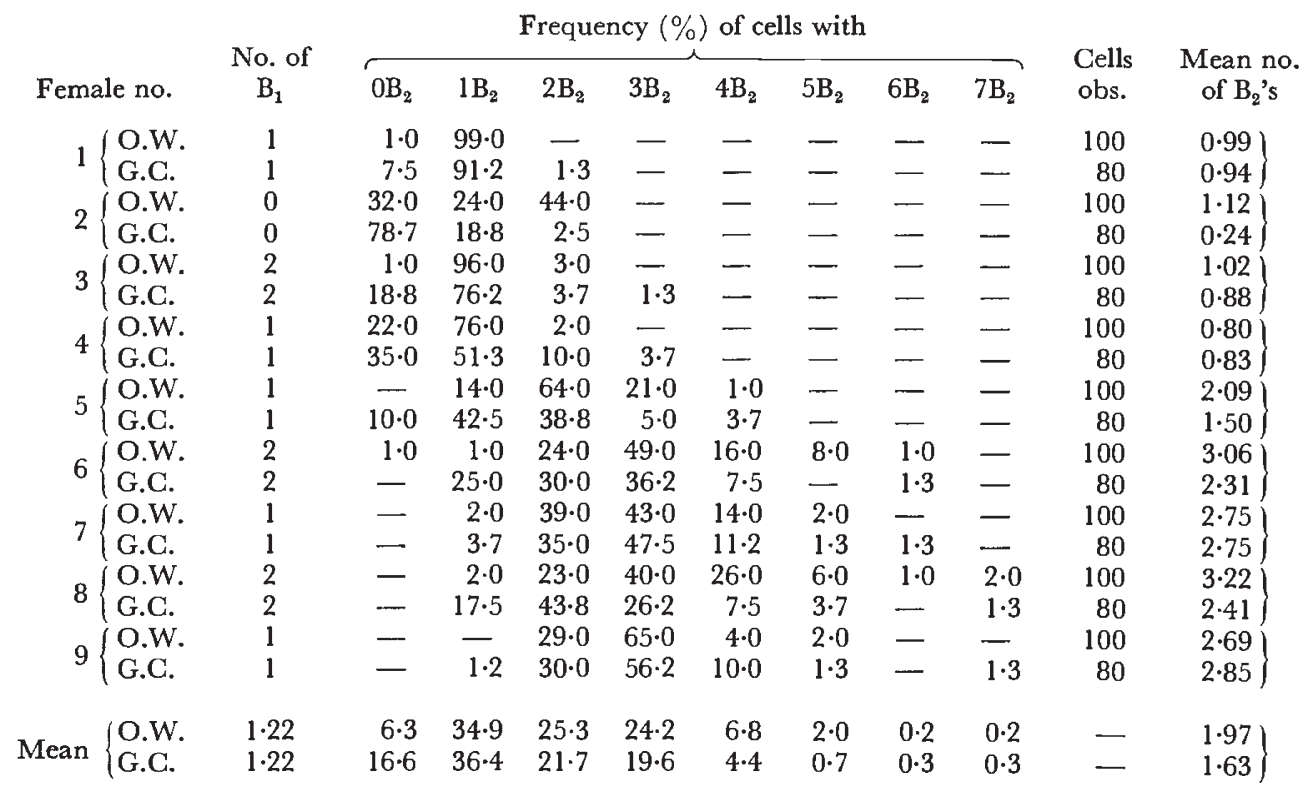

Second, frequencies of different types of sperms to be produced in the males were calculated on the basis of frequencies of different follicle types and frequencies of pairing configurations of $\mathrm{B}_{2}$ 's at MI. If, for example, the cells with 1 II of $B_{2}$ 's gave rise to sperms all with $1 B_{2}$ and those with 2 I's gave rise to the sperms with $0 \mathrm{~B}_{2}, 1 \mathrm{~B}_{2}$ and $2 \mathrm{~B}_{2}$ 's in the ratio $1: 2: 1$, the follicles with $2 \mathrm{~B}_{2}$ 's $(17 \cdot 1$ per cent) would produce sperms with 0,1 and $2 \mathrm{~B}$ 's in the frequencies $0.817,15.467$ and 0.817 per cent, respectively, since in the follicles with 2B's 80.9 per cent were cells with 1 II and 19.1 per cent were cells with 2 I's (cf. table l). On such assumptions relationships between follicle types and the resulting gametic types were calculated as shown in table 9. Then, the frequencies of the gametes produced in this population was calculated to be $21 \cdot 36\left(0 \mathrm{~B}_{2}\right), 38.98\left(1 \mathrm{~B}_{2}\right), 23 \cdot 20\left(2 \mathrm{~B}_{2}{ }^{\prime} \mathrm{s}\right)$, and so forth (table 9).

Third, frequencies of zygotic types in next generation were calculated assuming that the frequency distributions of $B_{2}$ 's in the eggs were the same as in the sperms, and matings took place at random. Then, among 13 zygotes 0.59 would be individuals without $\mathrm{B}_{2}, 2 \cdot 17$ with $1 \mathrm{~B}_{2}, 3.27$ with $2 \mathrm{~B}_{2}$ 's 2.90 with $3 \mathrm{~B}_{2}$ 's and so on (table 8 ). These values are rather close to those of the 
TABLE 5

Frequencies of $B$ 's in natural populations of $\mathrm{G}$. bicolor

1. Gs

No. of males with

No. of males without

$$
\mathrm{B}_{2} \text { 's }
$$

No. of males with $B_{2}$ 's

Total

$(\%)$

\begin{tabular}{|c|c|c|c|c|c|}
\hline $0 B_{1}$ & $1 B_{1}$ & $2 \mathrm{~B}_{1}$ & $3 \mathrm{~B}_{1}$ & Total & $(\%)$ \\
\hline- & 1 & - & - & 1 & $(2 \cdot 9)$ \\
\hline 25 & 7 & 2 & 一 & 34 & $(97 \cdot 1)$ \\
\hline 25 & 8 & 2 & - & 35 & $(100.0)$ \\
\hline$(71 \cdot 4)$ & & $(28$ & & $(100 \cdot 0)$ & - \\
\hline
\end{tabular}

Mean no. of $\mathrm{B}_{1}$ 's per male

\section{2. $K s$}

No. of males with

No. of males without $\mathrm{B}_{2}$ 's

No. of males with $B_{2}$ 's Total

\begin{tabular}{|c|c|c|c|c|c|}
\hline \multicolumn{6}{|c|}{ No. of males with } \\
\hline $\mathrm{OB}_{1}$ & $1 \mathrm{~B}_{1}$ & $2 \mathrm{~B}_{1}$ & $3 \mathrm{~B}_{1}$ & Total & $(\%)$ \\
\hline - & 1 & - & - & 1 & $(5 \cdot 0)$ \\
\hline 13 & 4 & 1 & 1 & 19 & $(95 \cdot 0)$ \\
\hline 13 & 5 & 1 & 1 & 20 & $(100.0)$ \\
\hline$(65 \cdot 0)$ & & $(35 \cdot 0)$ & & $(100 \cdot 0)$ & 一 \\
\hline
\end{tabular}

No. of males without

$\mathrm{B}_{2}$ 's
No. of males with $\mathrm{B}_{2}$ 's

Total

$(\%)$

No. of males without

$$
\mathrm{B}_{2} \text { 's }
$$

No. of males with $B_{2}$ 's Total

No. of females without $\mathrm{B}_{2}$ 's

No. of females with $B_{2}$ 's
3. $O t$

No. of males with

$\begin{array}{cccccc}0 \mathrm{~B}_{1} & 1 \mathrm{~B}_{1} & 2 \mathrm{~B}_{1} & 3 \mathrm{~B}_{1} & \text { Tstal } & (\%) \\ 7 & - & - & - & 7 & (24 \cdot 1) \\ 18 & 4 & - & - & 22 & (75 \cdot 9) \\ 25 & \underbrace{4}_{(86 \cdot 2)} & - & - & 29 & (100 \cdot 0) \\ (13 \cdot 8) & & (100 \cdot 0) & -\end{array}$

4. $K g$

\begin{tabular}{|c|c|c|c|c|c|}
\hline $0 \mathrm{~B}_{1}$ & $1 B_{1}$ & $2 \mathrm{~B}_{1}$ & $3 B_{1}$ & Total & $(\%)$ \\
\hline - & 1 & - & 1 & 2 & $(8 \cdot 0)$ \\
\hline 7 & 11 & 5 & - & 23 & $(92 \cdot 0)$ \\
\hline 7 & 12 & 5 & 1 & 25 & $(100 \cdot 0)$ \\
\hline$(28 \cdot 0)$ & & $(72 \cdot 0$ & & $(100 \cdot 0)$ & - \\
\hline
\end{tabular}

No. of males with

\begin{tabular}{|c|c|c|c|c|c|}
\hline $0 \mathrm{~B}_{1}$ & $1 B_{1}$ & $2 \mathrm{~B}_{1}$ & $3 \mathrm{~B}_{1}$ & Total & $(\%)$ \\
\hline - & - & 一 & - & 一 & $(0 \cdot 0)$ \\
\hline 1 & 5 & 3 & - & 9 & $(100 \cdot 0)$ \\
\hline$(11 \cdot 1)$ & & $(88.9$ & & $(100 \cdot 0)$ & - \\
\hline
\end{tabular}

No. of females with
Mean no. of $B_{1}$ 's per male

Mean no. of $B_{1}$ 's per male

Mean no. of $B_{1}$ 's per male

Mean no. of $B_{1}$ 's per female

$\overline{1 \cdot 22}$ 
Table 8

Estimation of original zygotic numbers of $B_{2}$ 's in 13 males from the $\mathrm{Kg}$ population

Frequency of

$\%$ follicles in the males*

$\%$ gametes produced by the males $†$

Zygotes estimated

Males inferred from follicle types

Males inferred from cells of G.C.

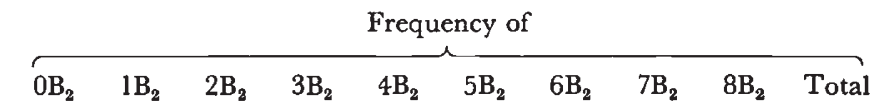

Mean no. of $\mathrm{B}_{2}$ 's

$\begin{array}{llllllllll}7 \cdot 7 & 23 \cdot 1 & 17 \cdot 1 & 20 \cdot 5 & 14 \cdot 6 & 3.7 & 5 \cdot 0 & 5 \cdot 7 & 2 \cdot 6 & 100 \cdot 0\end{array}$

\section{$2 \cdot 86$}

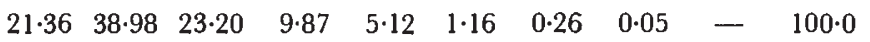

$0.59 \quad 2$

$\begin{array}{lccc}3 & 2 & 2 & - \\ 5 & - & - & 1 \\ & * & \text { Cf. table } 3 \\ & + \text { Cf. table } 6\end{array}$

TABLE 9

Frequency of sperms to be produced by 13 males shown in table 3

\begin{tabular}{|c|c|c|c|c|c|c|c|c|c|c|c|}
\hline \multirow{2}{*}{\multicolumn{2}{|c|}{ Spermatocytes }} & \multicolumn{10}{|c|}{ Sperms (\%) } \\
\hline & & $0 B_{2}$ & $1 B_{2}$ & $2 \mathrm{~B}_{2}$ & $3 \mathrm{~B}_{2}$ & $4 B_{2}$ & $5 B_{2}$ & $6 B_{2}$ & $7 B_{2}$ & $8 \mathrm{~B}_{2}$ & Total \\
\hline \multirow{2}{*}{\multicolumn{2}{|c|}{$\begin{array}{l}0 B_{2} \\
1 B_{2}\end{array}$}} & $7 \cdot 700$ & - & - & - & - & - & - & - & - & $7 \cdot 70$ \\
\hline & & $11 \cdot 550$ & $11 \cdot 550$ & - & - & - & - & - & - & - & $23 \cdot 10$ \\
\hline & ( I II & - & $13 \cdot 834$ & - & - & - & - & - & - & - & \\
\hline & $2 \mathrm{I}$ & 0.817 & 1.633 & 0.817 & - & - & - & - & - & - & $17 \cdot 10$ \\
\hline & $1 \mathrm{III}$ & - & $0 \cdot 103$ & $0 \cdot 103$ & - & - & - & - & - & - & \\
\hline \multirow[t]{4}{*}{$3 B_{2}$} & $1 \mathrm{II}+1 \mathrm{I}$ & - & $5 \cdot 658$ & $5 \cdot 658$ & - & - & 一 & - & - & - & $20 \cdot 50$ \\
\hline & $3 \mathrm{I}$ & $1 \cdot 122$ & $3 \cdot 367$ & $3 \cdot 367$ & $1 \cdot 122$ & - & - & - & - & - & \\
\hline & $1 \mathrm{IV}$ & - & $0 \cdot 010$ & 0.010 & 0.010 & - & - & - & - & - & \\
\hline & $1 \mathrm{III}+1 \mathrm{I}$ & - & 0.033 & $0 \cdot 066$ & $0 \cdot 033$ & - & - & 一 & - & - & \\
\hline \multirow[t]{5}{*}{$4 B_{2}$} & $2 \mathrm{II}$ & - & - & $5 \cdot 548$ & - & - & - & - & - & - & $14 \cdot 60$ \\
\hline & $1 \mathrm{II}+2 \mathrm{I}$ & - & $1 \cdot 697$ & $3 \cdot 394$ & 1.697 & - & - & - & - & - & \\
\hline & $4 \mathrm{I}$ & $0 \cdot 131$ & 0.526 & 0.788 & 0.526 & $0 \cdot 131$ & - & - & - & - & \\
\hline & $1 \mathrm{IV}+1 \mathrm{I}$ & - & 0.004 & 0.009 & 0.009 & 0.004 & - & - & - & - & \\
\hline & $1 \mathrm{III}+1 \mathrm{II}$ & - & - & $0 \cdot 013$ & $0 \cdot 013$ & - & - & - & - & - & \\
\hline \multirow{6}{*}{$5 B_{2}$} & $1 \mathrm{III}+2 \mathrm{I}$ & - & $0 \cdot 007$ & $0 \cdot 021$ & $0 \cdot 021$ & $0 \cdot 007$ & - & - & - & - & \\
\hline & $2 I I+1 I$ & - & - & 0.701 & 0.701 & - & - & - & - & - & $3 \cdot 70$ \\
\hline & $1 \mathrm{II}+3 \mathrm{I}$ & - & $0 \cdot 184$ & $0 \cdot 551$ & 0.551 & $0 \cdot 184$ & - & - & - & - & \\
\hline & $5 \mathrm{I}$ & 0.023 & $0 \cdot 113$ & $0 \cdot 225$ & $0 \cdot 225$ & $0 \cdot 113$ & 0.023 & - & - & - & \\
\hline & $1 \mathrm{III}+3 \mathrm{I}$ & - & $0 \cdot 004$ & $0 \cdot 016$ & 0.024 & 0.016 & 0.004 & - & - & - & \\
\hline & $3 \mathrm{II}$ & - & - & - & 0.825 & - & - & - & - & - & \\
\hline \multirow[t]{5}{*}{$6 \mathrm{~B}_{2}$} & $2 \mathrm{II}+2 \mathrm{I}$ & - & - & 0.621 & $1 \cdot 243$ & $0 \cdot 621$ & - & - & - & - & $5 \cdot 00$ \\
\hline & $1 \mathrm{II}+4 \mathrm{I}$ & - & 0.089 & $0 \cdot 356$ & 0.534 & 0.356 & 0.089 & - & - & - & \\
\hline & $6 \mathrm{I}$ & 0.003 & 0.019 & 0.047 & 0.062 & 0.047 & 0.019 & 0.003 & - & - & \\
\hline & $3 \mathrm{II}+1 \mathrm{I}$ & - & - & - & 0.271 & 0.271 & - & - & - & - & \\
\hline & $2 \mathrm{II}+3 \mathrm{I}$ & 一 & - & $0 \cdot 272$ & 0.815 & 0.815 & 0.272 & - & - & - & \\
\hline \multirow[t]{2}{*}{$7 \mathrm{~B}_{2}\{$} & $1 \mathrm{II}+5 \mathrm{I}$ & - & $0 \cdot 068$ & 0.339 & 0.679 & 0.679 & 0.339 & 0.068 & - & - & $5 \cdot 70$ \\
\hline & $7 \mathrm{I}$ & 0.006 & 0.045 & $0 \cdot 134$ & 0.223 & $0 \cdot 223$ & 0.134 & 0.045 & 0.006 & - & \\
\hline \multirow{2}{*}{$8 B_{2} *\{$} & $4 \mathrm{II}$ & - & - & - & - & $1 \cdot 300$ & - & - & - & - & \\
\hline & & 0.005 & 0.041 & $0 \cdot 142$ & 0.284 & $0 \cdot 356$ & 0.284 & $0 \cdot 142$ & 0.041 & 0.005 & \\
\hline \multicolumn{2}{|l|}{ Tot } & $21 \cdot 36$ & 38.98 & $23 \cdot 20$ & $9 \cdot 87$ & $5 \cdot 12$ & $1 \cdot 16$ & $0 \cdot 26$ & 0.05 & - & $100 \cdot 00$ \\
\hline
\end{tabular}

* Pairing configurations of $\mathrm{B}_{2}$ 's in spermatocytes of the follicles was not analysed. 
later stages. In Festuca pratensis (Bosemark, 1956) the rate of mitotic nondisjunction of the B's in pollen grain is affected by interaction between the B's, and in Lilium callosum coexistence of the $f_{l}$ type of B's enhance the rate of non-disjunction of another type of B's, $f_{s}$ (Kayano, 1962). In G. bicolor the frequency of males with varying number of $\mathrm{B}_{2}$ 's is higher in the population with higher mean number of $\mathrm{B}_{2}$ 's per follicle (table 7), suggesting that interaction between the $\mathrm{B}_{2}$ 's enhance the rate of their mitotic non-disjunction. The same type of interaction of B's has been reported in Scilla scilloides (Haga, 1961).

(ii) Difference in number of $B_{2}{ }^{\prime}$ s between somatic and germ lines

Nur (1963) suggested originally that variation in the number of B's due to non-disjunction would be maintained in association with an accumulation mechanism. This is the case in Camnula pellucida (Nur, 1969) and Locusta migratoria (Nur, 1969; Kayano, 1971), in which the mean numbers of B's per primary spermatocyte were higher than the means per cell of the gastric caeca. In G. bicolor, however, mitotic instability of $\mathrm{B}_{2}$ 's in the germ line is not likely to be associated with an accumulation mechanism because increase and decrease of number of $\mathrm{B}_{2}$ 's tend to be balanced within the population and the mean number of $\mathrm{B}_{2}$ 's in the primary spermatocytes is very close to the mean of the estimated original zygotic number. Therefore, lower mean numbers of $\mathrm{B}_{2}$ 's per cell in the somatic line than in the germ line is very likely to indicate true elimination of $\mathrm{B}_{2}$ 's from the somatic line.

\section{(iii) Difference between populations}

In spite of different frequencies of $\mathrm{B}_{1}$ 's and $\mathrm{B}_{2}$ 's between populations of $G$. bicolor both types of the B's occur in all four localities, suggesting that the populations have descended from a common ancestral population but nowadays they are more or less isolated from one another (cf. Hewitt and John, 1970; Kayano, Sannomiya and Nakamura, 1970). Evans (1960) has reported that two populations of Helix pomatia are different in the frequency of individuals with B's (mitotically unstable) and the cause is ascribed to historical difference between the populations. In Myrmeleotettix maculatus climatic differences and differences in transmission rates between the populations affect equilibrium frequencies of B's (Hewitt and Brown, 1970; Hewitt, 1973). Some of these explanations may be applicable to the population differences in G. bicolor. However, another explanation is also possible that the population may be different for the genotypes affecting tolerance to any harmful effect of the B's (cf. Östergren, 1947).

Acknowledgments.--The writer wishes to express his sincere appreciation to Professor $\mathrm{T}$. Haga, Department of Biology, Faculty of Science, Kyushu University, for his guidance and for his invaluable suggestions and criticisms in the preparation of the manuscript. The writer is indebted to Professor H. Kayano, Institute of Biology, Faculty of Liberal Arts, Nagasaki University, for helpful suggestions, and to Mr Koya Nakamura for co-operation in cytological handlings of the materials collected at Kashii.

\section{ReFERENCES}

Battaglia, E. 1964. Cytogenetics of B-chromosomes. Caryologia, 17, 249-299.

BOSEMARK, N. O. 1956. On accessory chromosomes in Festuca platensis. III. Frequency and geographical distribution of plants with accessory chromosomes. Hereditas, 42, 189-210. EVANS, H. J. 1960. Supernumerary chromosomes in wild population in the snail Helix pomatia L. Heredity, 15, 129-138. 


\section{Plate I}

(All figs. $\times 1000)$

Chromosomes of $G$. bicolor. Long and short arrows indicate $\mathrm{B}_{1}$ and $\mathrm{B}_{2}$, respectively.

Fig. 1.-A cell of a gastric caecum from a female, $2 n=22+\mathrm{XX}+1 \mathrm{~B}_{1}+3 \mathrm{~B}_{2}$.

Fig. 2.-A cell of a gastric caecum from a male, $2 n=22+\mathrm{XO}+2 \mathrm{~B}_{2}$.

Fig. 3.-A primary spermatocyte at diplotene, showing

$$
11 \mathrm{II}+\mathrm{X}+1 \mathrm{II}\left(\mathrm{B}_{1}\right)+1 \mathrm{II}+5 \mathrm{I}\left(\mathrm{B}_{2}\right) \text {. }
$$

Figs. 4-7.-MI's of primary spermatocytes from different follicles of a male; $3 \mathrm{~B}_{2}, 4 \mathrm{~B}_{2}, 5 \mathrm{~B}_{2}$, and $7 \mathrm{~B}_{2}$, respectively. 


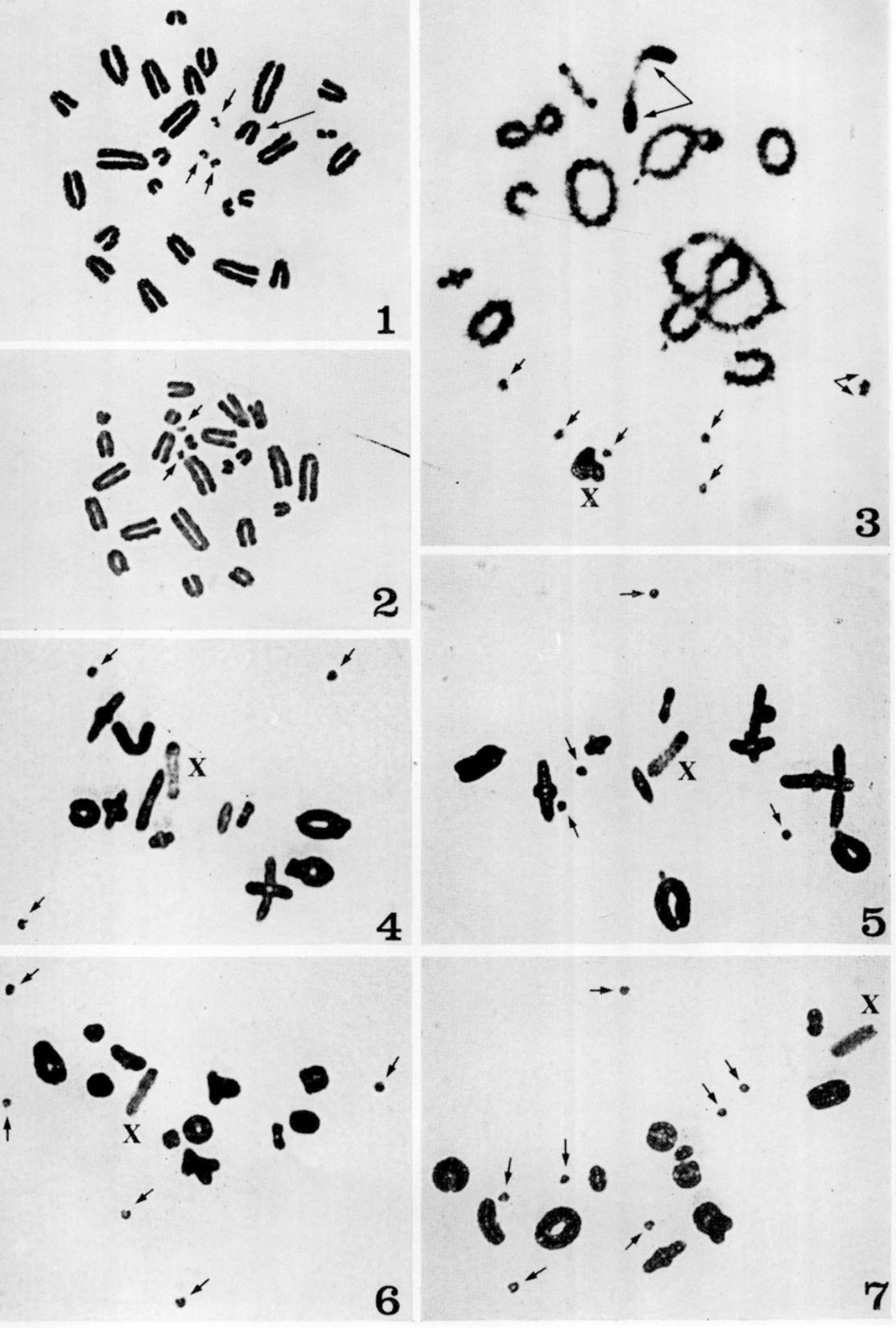


GRUN, P. 1959. Variability of accessory chromosomes in native populations of Allium cernuum. Amer. F. Bot., 46, 218-224.

HAGA, T. 1961. Intra-individual variation in number and linear patterning of the chromosomes. I. B-chromosomes in Rumex, Paris, and Scilla. Proc. Fapan Acad., 37, 627-632.

HEWITT, G. 1973. A variable transmission rates of B-chromosome in Myrmeleotettix maculatus (Thunb.) (Acrididae: Orthoptera). Chromosoma, 40, 83-106.

HEWITT, G. M., AND BROWN, M. F. 1970. The B-chromosome system of Myrmeleotettix maculatus. V. A steep cline in East Anglia. Heredity, 25, 363-371.

HeWITT, G. M., AND JOHN, в. 1970. The B-chromosome system of Myrmeleotettix maculatus (Thunb.). IV. The dynamics. Evolution, 24, 169-180.

John, в., AND LeWis, к. R. 1968. The chromosome complement. Protoplasmatologia, 4. Springer-Verlag.

KAYANO, H. 1962. Cytogenetic studies in Lilium callosum. IV. Transmission and multiplication of a small supernumerary $\mathrm{B}$ chromosomes. Evolution, 16, 86-89.

KAYANO, H. 1971. Accumulation of B chromosomes in the germ line of Locusta migratoria. Heredity, 27, 119-123.

Kayano, H., SANNOMIYA, M., AND NAKamuRA, K. 1970. Cytogenetic studies on natural populations of Acrida lata. Heredity, 25, 113-122.

MüntZING, A. 1958. Accessory chromosomes. Trans. Bose Res. Inst. (Calcutta), 22, 1-15. MüNTZING, A. 1966. Accessory chromosomes. Bull. Bot. Soc. Bengal, 20, 1-15.

NEWCOMER, E. H. 1953. A new cytological and histological fixing fluid. Science, 118, 161. NUR, U. 1963. A mitotically unstable supernumerary chromosome with an accumulation mechanism in a grasshopper. Chromosoma, 14, 407-422.

NUR, U. 1969. Mitotic instability leading to an accumulation of B-chromosomes in grasshoppers. Chromosoma, 27, 1-19.

östergren, G. 1947. Heterochromatic B-chromosome in Anthoxanthum. Hereditas, 33, 261296.

rutrshauser, A. 1960. Zur Genetik überzäliger Chromosomen. Arch. F. Klaus-Stift. Vererb. Sozial. Rass. (Zürich), 35, 440-458.

SANNOMIYA, M., AND KAYANO, H. 1969. Local variation and year-to-year change in frequencies of B-chromosomes in natural populations of two grasshopper species. Fapan $\mathcal{F}$. Genetics, 44, Suppl. 1, 84-92.

sNow, R. 1963. Alcoholic hydrochloric acid-carmine as a stain for chromosomes in squash preparations. Stain Technol., 2, 116-117.

white, м. J. D. 1954. Animal Cytology and Evolution, 2nd ed. Cambridge Univ. Press, Cambridge. 


\section{Appendix tables}

APPENDIX TABLE 1

Frequencies of $B$ 's in the Gs population of $\mathrm{G}$. bicolor Number of follicles with

\begin{tabular}{|c|c|c|c|c|c|c|c|c|c|c|c|c|c|}
\hline \multirow{2}{*}{$\begin{array}{c}\text { No. of } \\
B_{1}\end{array}$} & \multicolumn{10}{|c|}{ Number of follicles with } & \multirow[b]{2}{*}{$\begin{array}{l}\text { No. of } \\
\text { folls. }\end{array}$} & \multirow{2}{*}{\multicolumn{2}{|c|}{$\begin{array}{c}\text { Mean no. of } \\
\mathrm{B}_{2} \text { 's per } \\
\text { follicle }\end{array}$}} \\
\hline & $\begin{array}{l}\text { Male } \\
\text { no. }\end{array}$ & $0 \mathrm{~B}_{2}$ & $1 \mathrm{~B}_{2}$ & $2 \mathrm{~B}_{2}$ & $3 B_{2}$ & $4 B_{2}$ & $5 B_{2}$ & $6 \mathrm{~B}_{2}$ & $9 B_{2}$ & $13 B_{2}$ & & & \\
\hline & 1 & - & 5 & - & - & - & - & - & - & - & 5 & 169 & $1 \cdot 00$ \\
\hline & 2 & - & 7 & - & - & - & - & - & - & - & 7 & 409 & $1 \cdot 00$ \\
\hline & 3 & - & 7 & $1^{a}$ & 1 & - & - & - & - & - & 9 & 309 & $1 \cdot 33$ \\
\hline & 4 & - & 1 & 2 & 1 & 一 & - & - & - & - & 4 & 32 & $2 \cdot 00$ \\
\hline & 5 & - & 1 & - & - & - & $2^{b}$ & 1 & 1 & - & 5 & 107 & $5 \cdot 20$ \\
\hline & 6 & - & - & 2 & - & - & - & - & - & - & 2 & 66 & $2 \cdot 00$ \\
\hline & 7 & - & - & 1 & - & - & - & - & - & - & 1 & 27 & $2 \cdot 00$ \\
\hline & 8 & - & - & 3 & - & - & - & - & - & - & 3 & 24 & $2 \cdot 00$ \\
\hline & 9 & - & - & 6 & 1 & - & - & - & - & - & 7 & 264 & $2 \cdot 14$ \\
\hline & 10 & - & - & 3 & 1 & - & - & - & - & - & 4 & 84 & $2 \cdot 25$ \\
\hline & 11 & - & - & 3 & 1 & 1 & - & - & - & - & 5 & 125 & $2 \cdot 60$ \\
\hline & 12 & - & - & 1 & 3 & 2 & - & - & - & - & 6 & 211 & 3.17 \\
\hline $0 B_{1}$ & 13 & - & - & 2 & 4 & 1 & 1 & - & - & - & 8 & 95 & $3 \cdot 13$ \\
\hline & 14 & - & - & 1 & - & 2 & 2 & 1 & - & - & 6 & 87 & $4 \cdot 33$ \\
\hline & 15 & - & - & 1 & 2 & - & - & 2 & - & - & 5 & 117 & $4 \cdot 00$ \\
\hline & 16 & - & - & - & 9 & - & - & - & - & - & 9 & 312 & 3.00 \\
\hline & 17 & - & - & - & 1 & - & - & - & - & - & 1 & 32 & 3.00 \\
\hline & 18 & - & - & - & 3 & 1 & - & - & - & - & 4 & 130 & $3 \cdot 25$ \\
\hline & 19 & - & - & - & 2 & 3 & - & - & - & - & 5 & 77 & 3.60 \\
\hline & 20 & - & - & - & 2 & 2 & - & - & - & - & 4 & 91 & $3 \cdot 50$ \\
\hline & 21 & - & - & - & 1 & 6 & 1 & - & - & - & 8 & 126 & $4 \cdot 00$ \\
\hline & 22 & - & - & - & 1 & 3 & - & 2 & - & - & 6 & 145 & $4 \cdot 50$ \\
\hline & 23 & - & - & - & - & 7 & - & - & - & - & 7 & 94 & $4 \cdot 00$ \\
\hline & 24 & - & - & - & - & 1 & - & - & - & - & 1 & 24 & $4 \cdot 00$ \\
\hline & 25 & - & - & - & - & 1 & - & 2 & - & - & 3 & 87 & $5 \cdot 33$ \\
\hline & 26 & 3 & - & - & - & - & - & - & - & - & 3 & 114 & 0.00 \\
\hline & 27 & - & 2 & 3 & - & - & - & - & - & - & 5 & 117 & 1.60 \\
\hline & 28 & - & I & 3 & - & 1 & - & - & - & - & 5 & 120 & $2 \cdot 20$ \\
\hline $1 B_{1}$ & 29 & - & - & 4 & - & - & - & - & - & - & 4 & 150 & $2 \cdot 00$ \\
\hline & 30 & - & - & 2 & - & 1 & - & - & - & - & 3 & 96 & $2 \cdot 67$ \\
\hline & 31 & - & - & 1 & - & 1 & - & - & - & 1 & 3 & 47 & $6 \cdot 33$ \\
\hline & 32 & - & - & - & 5 & - & 1 & - & - & - & 6 & 134 & $3 \cdot 33$ \\
\hline & 33 & - & - & - & - & - & 1 & 1 & - & - & 2 & 23 & $5 \cdot 50$ \\
\hline & 34 & 1 & 5 & 1 & - & - & - & - & - & - & 7 & 81 & $1 \cdot 00$ \\
\hline $2 \mathrm{~B}_{1}$ & 35 & 一 & - & 2 & $2^{*}$ & - & - & - & - & - & 4 & 113 & $2 \cdot 50$ \\
\hline Total & - & 4 & 29 & 42 & 40 & 33 & 8 & 9 & 1 & 1 & 167 & - & Mean 2.96) \\
\hline $\begin{array}{l}\text { No. of } \\
\text { cells }\end{array}$ & - & 130 & 973 & 1087 & 1046 & 682 & 113 & 189 & 15 & 4 & - & 4239 & - \\
\hline
\end{tabular}

$a, b$ Each indicates the follicle with variable number of $\mathrm{B}_{2}$ 's given in the text.

* Indicates inclusion of a follicle with variable number of $\mathrm{B}_{1}$ 's given in the text as case 1 . 
Appendix table 2

Frequencies of $B$ 's in the $K s$ population of $\mathrm{G}$. bicolor

\begin{tabular}{|c|c|c|c|c|c|c|c|c|c|c|c|c|}
\hline \multirow[b]{2}{*}{$\begin{array}{c}\text { No. of } \\
B_{1}\end{array}$} & \multirow[b]{2}{*}{$\begin{array}{c}\text { Male } \\
\text { no. }\end{array}$} & \multicolumn{8}{|c|}{ Number of follicles with } & \multirow[b]{2}{*}{$\begin{array}{l}\text { No. of } \\
\text { folls. }\end{array}$} & \multirow{2}{*}{\multicolumn{2}{|c|}{$\begin{array}{l}\text { Mean no. of } \\
\mathrm{B}_{2} \text { 's per } \\
\text { follicle }\end{array}$}} \\
\hline & & $0 \mathrm{~B}_{2}$ & $1 \mathrm{~B}_{2}$ & $2 \mathrm{~B}_{2}$ & $3 \mathrm{~B}_{2}$ & $4 \mathrm{~B}_{2}$ & $5 \mathrm{~B}_{2}$ & $6 \mathrm{~B}_{2}$ & $7 \mathrm{~B}_{2}$ & & & \\
\hline \multirow{14}{*}{$0 \mathrm{~B}_{1}$} & 1 & 1 & 6 & - & - & - & - & - & - & 7 & 101 & $0 \cdot 86$ \\
\hline & 2 & - & 9 & - & - & - & - & - & - & 9 & 118 & $1 \cdot 00$ \\
\hline & 3 & - & 6 & - & - & - & - & - & - & 6 & 91 & $1 \cdot 00$ \\
\hline & 4 & - & 7 & - & - & - & - & - & - & 7 & 229 & 1.00 \\
\hline & 5 & - & 4 & - & - & - & - & - & - & 4 & 82 & 1.00 \\
\hline & 6 & - & 5 & 2 & - & - & - & - & - & 7 & 205 & 1.29 \\
\hline & 7 & - & 1 & 2 & - & - & - & - & - & 3 & 117 & 1.67 \\
\hline & 8 & - & 1 & 3 & - & - & - & - & - & 4 & 68 & $1 \cdot 75$ \\
\hline & 9 & - & - & 7 & - & - & - & - & - & 7 & 163 & $2 \cdot 00$ \\
\hline & 10 & - & - & 1 & 3 & 1 & - & - & - & 5 & 225 & 3.00 \\
\hline & 11 & - & - & 6 & 1 & - & 1 & - & - & 8 & 279 & $2 \cdot 50$ \\
\hline & 12 & - & - & - & 2 & 1 & - & - & - & 3 & 35 & $3 \cdot 33$ \\
\hline & 13 & - & - & - & 1 & 2 & 2 & - & 1 & 6 & 161 & $4 \cdot 67$ \\
\hline & 14 & 6 & - & - & - & - & - & - & - & 6 & 165 & 0.00 \\
\hline \multirow{4}{*}{$1 B_{1}$} & 15 & - & 4 & - & - & - & - & - & - & 4 & 78 & 1.00 \\
\hline & 16 & - & 3 & - & - & - & - & - & - & 3 & 87 & 1.00 \\
\hline & 17 & - & - & 1 & 3 & - & - & - & - & 4 & 27 & $2 \cdot 75$ \\
\hline & 18 & - & - & $1^{c}$ & 7 & 2 & - & - & - & 10 & 544 & $3 \cdot 10$ \\
\hline $2 \mathrm{~B}_{1}$ & 19 & - & 6 & 1 & - & - & - & - & - & 5 & 90 & 1.20 \\
\hline $3 \mathrm{~B}_{1}$ & 20 & - & 4 & $1 *$ & - & - & - & - & - & 5 & 46 & 1.20 \\
\hline Total & - & 7 & 54 & 25 & 17 & 6 & 3 & - & 1 & 113 & - & (Mean 1.77) \\
\hline $\begin{array}{l}\text { No. of } \\
\text { cells }\end{array}$ & - & 174 & 1142 & 613 & 699 & 201 & 61 & - & 21 & - & 2911 & - \\
\hline
\end{tabular}


Appendix table 3

Frequencies of $B$ 's in the Ot population of $\mathrm{G}$. bicolor

\begin{tabular}{|c|c|c|c|c|c|c|c|c|c|}
\hline \multirow[b]{2}{*}{$\begin{array}{c}\text { No. of } \\
B_{1}\end{array}$} & \multirow[b]{2}{*}{$\begin{array}{l}\text { Male } \\
\text { no. }\end{array}$} & \multicolumn{5}{|c|}{ No of follicles with } & \multirow[b]{2}{*}{$\begin{array}{l}\text { No. of } \\
\text { folls. }\end{array}$} & \multirow[b]{2}{*}{$\begin{array}{l}\text { No. of } \\
\text { cells }\end{array}$} & \multirow[b]{2}{*}{$\begin{array}{l}\text { Mean no. of } \mathrm{B}_{2} \text { 's } \\
\text { per follicle }\end{array}$} \\
\hline & & $\mathrm{OB}_{2}$ & $1 B_{2}$ & $2 \mathrm{~B}_{2}$ & $3 \mathrm{~B}_{2}$ & $4 \mathrm{~B}_{2}$ & & & \\
\hline \multirow{26}{*}{$\mathrm{OB}_{1}$} & 1 & 4 & - & - & - & - & 4 & 193 & 0.00 \\
\hline & 2 & 3 & - & - & - & - & 3 & 84 & $0 \cdot 00$ \\
\hline & 3 & 4 & - & - & - & - & 4 & 134 & $0 \cdot 00$ \\
\hline & 4 & 6 & - & - & - & - & 6 & 172 & 0.00 \\
\hline & 5 & 2 & - & - & - & - & 2 & 72 & $0 \cdot 00$ \\
\hline & 6 & 1 & - & - & - & - & 1 & 39 & $0 \cdot 00$ \\
\hline & 7 & 3 & - & - & - & - & 3 & 163 & $0 \cdot 00$ \\
\hline & 8 & 一 & 3 & - & - & - & 3 & 86 & $1 \cdot 00$ \\
\hline & 9 & - & 5 & - & - & - & 5 & 254 & 1.00 \\
\hline & 10 & - & 3 & - & - & - & 3 & 131 & $1 \cdot 00$ \\
\hline & 11 & - & 2 & 1 & - & - & 3 & 235 & 1.33 \\
\hline & 12 & - & 3 & 2 & - & - & 5 & 178 & 1.40 \\
\hline & 13 & - & 3 & 1 & - & - & 4 & 112 & $1 \cdot 25$ \\
\hline & 14 & - & 3 & 2 & - & - & 5 & 187 & 1.40 \\
\hline & 15 & - & 2 & 1 & - & - & 3 & 253 & 1.33 \\
\hline & 16 & - & 5 & 1 & - & - & 6 & 269 & $1 \cdot 17$ \\
\hline & 17 & - & - & 1 & - & - & 1 & 20 & $2 \cdot 00$ \\
\hline & 18 & - & - & 5 & - & - & 5 & 201 & $2 \cdot 00$ \\
\hline & 19 & - & - & 3 & - & - & 3 & 104 & $2 \cdot 00$ \\
\hline & 20 & - & - & 7 & 一 & - & 7 & 359 & $2 \cdot 00$ \\
\hline & 21 & - & - & 2 & - & - & 2 & 50 & $2 \cdot 00$ \\
\hline & 22 & - & - & 2 & 1 & - & 3 & 83 & $2 \cdot 33$ \\
\hline & 23 & - & - & - & 2 & - & 2 & 73 & $3 \cdot 00$ \\
\hline & 24 & - & - & - & - & 2 & 2 & 40 & $4 \cdot 00$ \\
\hline & 25 & - & - & - & - & 1 & 1 & 56 & $4 \cdot 00$ \\
\hline & 26 & - & 2 & - & - & - & 2 & 62 & $1 \cdot 00$ \\
\hline \multirow{3}{*}{$1 \mathrm{~B}_{1}$} & 27 & - & 2 & - & - & - & 2 & 124 & $1 \cdot 00$ \\
\hline & 28 & - & 1 & 1 & - & - & 2 & 39 & 1.50 \\
\hline & 29 & - & - & 4 & - & - & 4 & 37 & $2 \cdot 00$ \\
\hline Total & - & 23 & 34 & 33 & 3 & 3 & 96 & - & (Mean 1.37) \\
\hline No. of & & & & & & & & & \\
\hline cells & - & 857 & 1603 & 1164 & 90 & 96 & - & 3810 & - \\
\hline
\end{tabular}


Appendix table 4

Frequencies of $B$ 's in the $K g$ population of $\mathrm{G}$. bicolor

\begin{tabular}{|c|c|c|c|c|c|c|c|c|c|c|c|c|}
\hline \multirow{2}{*}{$\begin{array}{l}\text { No. of } \\
B_{1}\end{array}$} & \multirow[b]{2}{*}{$\begin{array}{c}\text { Male } \\
\text { no. }\end{array}$} & \multicolumn{9}{|c|}{ Number of follicles with $\dagger$} & \multirow{2}{*}{$\begin{array}{l}\text { No. of } \\
\text { folls. }\end{array}$} & \multirow{2}{*}{$\begin{array}{l}\text { Mean no. of } \\
\mathrm{B}_{2} \text { 's per } \\
\text { follicle }\end{array}$} \\
\hline & & $\mathrm{OB}_{2}$ & $1 \mathrm{~B}_{2}$ & $2 \mathrm{~B}_{2}$ & $3 \mathrm{~B}_{2}$ & $4 \mathrm{~B}_{2}$ & $5 B_{2}$ & $6 \mathrm{~B}_{2}$ & $7 B_{2}$ & $8 B_{2}$ & & \\
\hline \multirow{6}{*}{$0 \mathrm{~B}_{1}$} & $1^{*}$ & - & 1 & 5 & 2 & 1 & - & - & - & - & 9 & $2 \cdot 33$ \\
\hline & 2 & - & - & 18 & - & - & - & - & - & - & 18 & $2 \cdot 00$ \\
\hline & 3 & - & - & 3 & 3 & 4 & 2 & - & - & - & 12 & 3.42 \\
\hline & 4 & - & - & - & 18 & 1 & - & - & - & - & 19 & 3.05 \\
\hline & 5 & - & - & - & - & 7 & - & - & - & - & 7 & $4 \cdot 00$ \\
\hline & 6 & - & - & - & - & 2 & - & 1 & - & - & 3 & $4 \cdot 67$ \\
\hline \multirow{13}{*}{$1 \mathrm{~B}_{1}$} & $7 *$ & - & - & - & - & - & - & 1 & 5 & 3 & 9 & $7 \cdot 22$ \\
\hline & 8 & 19 & - & - & - & - & - & - & - & - & 19 & $0 \cdot 00$ \\
\hline & 9* & - & 10 & - & - & - & - & - & - & - & 10 & $1 \cdot 00$ \\
\hline & $10^{*}$ & - & 20 & - & - & - & - & - & - & - & 20 & 1.00 \\
\hline & 11 & - & 1 & 4 & 1 & - & - & - & - & - & 6 & 2.00 \\
\hline & $12^{*}$ & - & 4 & 8 & 4 & 2 & - & - & - & - & 18 & $2 \cdot 22$ \\
\hline & $13^{*}$ & - & 10 & 2 & 1 & - & 2 & - & - & - & 15 & $1 \cdot 80$ \\
\hline & $14 *$ & - & - & 10 & 1 & - & - & - & - & - & 11 & $2 \cdot 09$ \\
\hline & $15^{*}$ & - & - & 2 & 8 & 1 & - & - & - & - & 11 & 2.91 \\
\hline & $16^{*}$ & - & - & - & 14 & - & - & - & - & - & 14 & 3.00 \\
\hline & $17 *$ & - & - & - & 2 & 6 & 1 & - & - & - & 9 & 3.98 \\
\hline & $18^{*}$ & - & - & - & 2 & 14 & 1 & - & - & - & 17 & 3.94 \\
\hline & 19 & - & - & - & 2 & 10 & 1 & - & - & - & 13 & 3.92 \\
\hline \multirow{5}{*}{$2 \mathrm{~B}_{1}$} & 20 & - & 1 & 6 & - & - & - & - & - & - & 7 & 1.86 \\
\hline & 21 & - & - & 5 & 4 & 2 & - & $\ldots$ & - & - & 11 & 2.73 \\
\hline & 22 & - & - & - & 3 & 6 & 1 & 3 & - & - & 13 & $4 \cdot 31$ \\
\hline & 23 & - & - & - & - & 3 & 7 & 3 & - & - & 13 & $5 \cdot 00$ \\
\hline & $24 *$ & - & - & - & - & 1 & 2 & 6 & 2 & - & 11 & $5 \cdot 82$ \\
\hline $3 \mathrm{~B}_{1}$ & $25 *$ & 12 & - & - & - & - & - & - & - & - & 12 & $0 \cdot 00$ \\
\hline Total & - & 31 & 47 & 63 & 65 & 60 & 17 & 14 & 7 & 3 & 307 & (Mean 2.97) \\
\hline
\end{tabular}

* Indicates 13 males given in table 3 .

$\ddagger$ Follicle type was determined by the observation of over 20 cells. 